\title{
The Appropriate Calculation Cost of Goods Manufactured as Pricing Strategy for Small Sized Enterprises (SMEs)
}

\author{
Popon Rabia Adawia', Aprilia Puspasari², Ayu azizah ${ }^{3}$, Asep, Dede Mustomi \\ 1,2,3,4, 5 Universitas Bina Sarana Informatika \\ e-mail: 1 popon.pra@bsi.ac.id, ${ }^{2}$ aprilia.alp@bsi.ac.id, ${ }^{3}$ ayu.azz@bsi.ac.id, ${ }^{4}$ asep.aep@bsi.ac.id, \\ ${ }^{5}$ dede.ddo@bsi.ac.id

\begin{tabular}{ccc}
\hline Diterima & Direvisi & Disetujui \\
$15-12-2020$ & $09-01-2021$ & $11-01-2021$ \\
\hline
\end{tabular}

\begin{abstract}
This research aims to identify all production costs incurred in production, to calculate the cost of goods manufactured correctly using the Process Costing Method and decision makingfordetermining the selling price of shoes. The researchwastakenin one of small-sized enterprises shoe factory in East Karawang. The research method is descriptive comparative with a qualitative approach. The descriptive method is used to describe the production costs incurred in the production process including the raw materials costs, supporting materials costs, labor costs, and factory overhead costs. In this research, the data used are primary and secondary data. The COGM calculation results in show that there is variance calculation between company system and process costing method. It is due tocalculationsthat companiesdonotidentifyproductioncostsindetail, thereforethecompany's COGMcalculation is inaccurate. The COGM calculation appropriately can be the company's strategy to determine the selling price. so that company profits can continue to increase.
\end{abstract}

Keyword: Cost Of Goods Manufacture (COGM), Production Cost, Pricing Strategy, Selling Prices

\section{INTRODUCTION}

The development of the business world, especially in the industrial sector, has increased rapidly over time. All of kind the business are competing to win the competition. Many strategies are pursued with the hope that the business can continue to develop sustainably and continuously generate maximum profit. Although profit maximization is not the main goal of a company, the company will still optimize various ways to increase the value of the company. One way is to create a quality product but at a selling price that can be reached by consumers.

Production costs are neede to create a product. Production cost is the sum of the cost assigned to a product for a specific purpose (Garrison, R.H; Noreen, W.E; Brewer, 2013). Production costs will create the cost of good manufacture (COGM). Inaccurate in calculating COGM will effect to determine selling prices. High COGM due to the incorrect calculation causes the selling price to be high. High prices cause consumers difficulty in purchasing power. So they will move on to competing companies that sell at lower prices but with the same quality. Sales are declining over time, and losses cannot be avoided. Likewise, the selling price is too low due to inaccurate calculations of COGM, causing profit to decline. Managers make decisions through production costs, accuracy is very important, small mistakes have a big effect on company profits.

Small and medium-sized enterprises (SMEs) is a business with assets, revenue and personnel numbers that fall below certain limits. SMEs occupy a very important position in our national economy. They have been playing a main role in global economic and social development. In Indonesia, SMEs assist economic growth. SMEs also creates jobs and reduce unemployment. The faster the development of SMEs, the tighter competition. The competitive situation requires Amira Collection as one of the small-scale shoe-making industry that is currently developing to be able to innovate in developing products and competitive prices. The company produces process the goal is to stock up, so the method for calculating the cost of goods uses Process Costing. Amira Collection must strive to carry out a strategy by presenting an 
affordable selling price but of the highest quality. A part from the above, the most important thing is how the company calculates the right COGM as a pricing strategy to make maximum profit.

Price is very important to the survival of the business, this could negatively impact the product and the company's profitability if not determined correctly. Table 1 explains the various types of pricing objectives that steer pricing strategies.

\section{Table 1. Types of pricing objectives}

\begin{tabular}{|c|c|c|}
\hline $\begin{array}{l}\text { Oriented of } \\
\text { Profit }\end{array}$ & $\begin{array}{l}\text { Oriented } \\
\text { of Sales }\end{array}$ & $\begin{array}{l}\text { Oriented of } \\
\text { Status-quo }\end{array}$ \\
\hline $\begin{array}{l}\text { Organization } \\
\text { s will } \\
\text { maximize } \\
\text { their current } \\
\text { profits. In } \\
\text { this attempt } \\
\text { they evaluate } \\
\text { de- mand } \\
\text { and costs } \\
\text { accompanyi } \\
\text { ng the } \\
\text { alternate and } \\
\text { prices choose the } \\
\text { phoo that } \\
\text { price max- } \\
\text { will imize profits, } \\
\text { income, or } \\
\text { rate of return } \\
\text { on investment. } \\
\text { investment. }\end{array}$ & $\begin{array}{l}\text { Sales } \\
\text { objective } \\
\text { s are } \\
\text { essentiall } \\
\text { y } \\
\text { expresse } \\
\text { d in terms } \\
\text { of sales } \\
\text { volume } \\
\text { or market } \\
\text { share. } \\
\text { The } \\
\text { motivatio } \\
\text { n for for } \\
\text { setting } \\
\text { sales } \\
\text { volume } \\
\text { objective } \\
\text { s is to } \\
\text { create } \\
\text { growth in } \\
\text { sales or to } \\
\text { sustain } \\
\text { current } \\
\text { sales } \\
\text { levels. }\end{array}$ & $\begin{array}{l}\text { Sales quo } \\
\text { objectives } \\
\text { are tactical } \\
\text { goals that } \\
\text { encourage } \\
\text { competition } \\
\text { on factors } \\
\text { other than } \\
\text { price. } \\
\text { Organizatio } \\
\text { ns that base } \\
\text { their pricing } \\
\text { strategy on } \\
\text { this employ } \\
\text { such an } \\
\text { orientation } \\
\text { to remain } \\
\text { competitive } \\
\text { or to avoid } \\
\text { price battles } \\
\text { with their } \\
\text { competitors. }\end{array}$ \\
\hline
\end{tabular}

Source: (Michael Colin Cant, Jan Wiid, 2016)

Preliminary research on the calculation of the cost of good-manufactured has been written Decot, F.A, Corner, D.S. et al, Measuring the Costs of Production and Pricing on Diversified Farmers. In their research, they conducted in-depth interviews with various agricultural workers by using a constant comparison method to analyze data. From these studies, the results obtained are that for determining COGM and creating price for selling, there is no different for each farmer. And Dewi,M.W and Muryati, in their journal An anlysis of calculation of the Cost of Good Manufacture with the Order Price Method on Sales Pricing. Output of this research is that the calculation of cost of production based on the results of analysis using the full costing method is greater than the calculation of the cost of production method by a company.

None of these studies have discussed in detail the calculation of COGM based on process costing. Each type of production has different characteristics and costing methods, and the research conducted by this researcher is the calculation of COGM by using a process costing by adding equivalent units to the calculation and considering the elements of the defective product in the calculation of determining COGM. The hope from this research can be obtained from the calculation of the correct and accurate COGM as a reference for setting the selling price so that company profits can continue to increase.

\section{Cost of Goods Manufacture}

The calculation of the COGM in SMEs aims to meet the needs of both internal and external parties. In table 2, several theories about the cost of goods manufactured are presented.

\section{Process Costing}

Each company has a different method of calculating the COGM. The method of collecting the cost of goods can be grouped into two methods, namely job order costing and process costing.

Table 2. Theory Matrix of COGM

\begin{tabular}{|l|l|l|c|}
\hline No & Theory & Dimension & Synthesis \\
\hline 1 & $\begin{array}{l}\text { Cost of Good } \\
\text { Manufacture } \\
\text { (COGM) is in } \\
\text { the form of } \\
\text { production } \\
\text { costs related to } \\
\text { goods } \\
\text { completed in } \\
\text { one period } \\
\text { (Garrison, R.H; } \\
\text { Noreen, W.E; } \\
\text { Brewer, 2013) }\end{array}$ & $\begin{array}{l}\text { Production } \\
\text { period one }\end{array}$ & $\begin{array}{c}\text { Cost of Goods } \\
\text { Manufacture are all } \\
\text { used to produce an } \\
\text { item starting from } \\
\text { the purchase and } \\
\text { processing of raw } \\
\text { materials into }\end{array}$ \\
\hline $\begin{array}{l}\text { Good Cost of } \\
\text { Manufacture } \\
\text { (COGM) is the } \\
\text { total production } \\
\text { cost of the } \\
\text { goods that } \\
\text { were } \\
\text { completed and } \\
\text { transferred to } \\
\text { The FG } \\
\text { Inventory } \\
\text { during the } \\
\text { period } \\
\text { (Vand erberck } \\
\text { 2009) }\end{array}$ & $\begin{array}{l}\text { Total } \\
\text { production } \\
\text { cost }\end{array}$ & & $\begin{array}{c}\text { finished goods and } \\
\text { ready for sale } \\
\text { within a certain } \\
\text { period }\end{array}$ \\
\hline
\end{tabular}

Source: Researcher

In this research, the method used is process costing because of the company mass production. Companies that do mass production will collect production costs based on process costing (Michael R.K, 2011). Table 3 presents several theories regarding process costing.

Table 3. Theory Matrix of Process Costing 


\begin{tabular}{|c|c|c|c|}
\hline $\mathrm{No}$ & Theory & Dimension & Synthesis \\
\hline 1 & $\begin{array}{l}\text { Processing } \\
\text { costing applies } \\
\text { to production } \\
\text { involving a } \\
\text { continuous pulting } \\
\text { process resulting } \\
\text { in a high volume } \\
\text { of identical or } \\
\text { almost identical } \\
\text { units of output. } \\
\text { While there are } \\
\text { some } \\
\text { complexities } \\
\text { attached to } \\
\text { process costing, } \\
\text { the basic idea } \\
\text { involves nothing } \\
\text { more than } \\
\text { calculating an } \\
\text { average cost } \\
\text { each (Barfield, JT; } \\
\text { (Baiborn, CA and } \\
\text { Kinney, 2010) }\end{array}$ & $\begin{array}{l}\text { Continou } \\
\text { s process } \\
\text { Cost } \\
\text { incurred } \\
\text { in period } \\
\text { Total } \\
\text { Costs to } \\
\text { total } \\
\text { output }\end{array}$ & $\begin{array}{l}\text { Process costing is } \\
\text { collecting cost of } \\
\text { production which } \\
\text { costs are collected } \\
\text { for each unit in }\end{array}$ \\
\hline 2 & $\begin{array}{l}\text { Process costing } \\
\text { system a method } \\
\text { of accumulating } \\
\text { and assigning } \\
\text { costs to units of } \\
\text { production in } \\
\text { companies producing large } \\
\text { producing of } \\
\text { quantities homogeneous } \\
\text { products; } \\
\text { accumulates } \\
\text { costs by cost } \\
\text { component in } \\
\text { each production } \\
\text { department and } \\
\text { assigns costs to } \\
\text { units un using } \\
\text { equivalent units } \\
\text { of production } \\
\text { (Michael } \\
\text { R.K, 2011) }\end{array}$ & $\begin{array}{l}\text { Large } \\
\text { quantities } \\
\text { Homogen } \\
\text { ous } \\
\text { products } \\
\text { Productio } \\
\text { n } \\
\text { departme } \\
\text { nt } \\
\text { Unit } \\
\text { Equivalen } \\
\text { ts }\end{array}$ & $\begin{array}{c}\text { production } \\
\text { departemen by } \\
\text { devided total costs } \\
\text { to total output }\end{array}$ \\
\hline
\end{tabular}

Source: Researcher

\section{Pricing Strategy}

This study describes the calculation of the COGM that is right and true as pricing strategies. External and Internal effects on the Pricing Strategy when SME develops their pricing strategy, they need to be aware of the factors that can assist them in their pricing decisions. Sometimes SME's require to consider the consumer's ability and willingness to pay a premium for the product offering. If the consumer cannot afford the product they will not purchase the product even if the quality is good. There is some factors that SMEs need to be aware of are described in Figure 1.

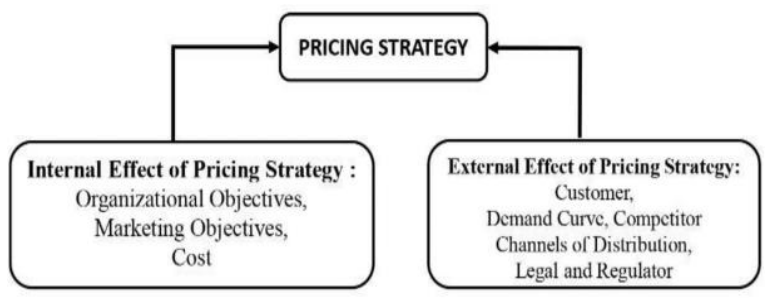

Source : (Brassington, F and Pettitt, 2013:258-267)

Figure 1. External and Internal Effects of Pricing Strategy

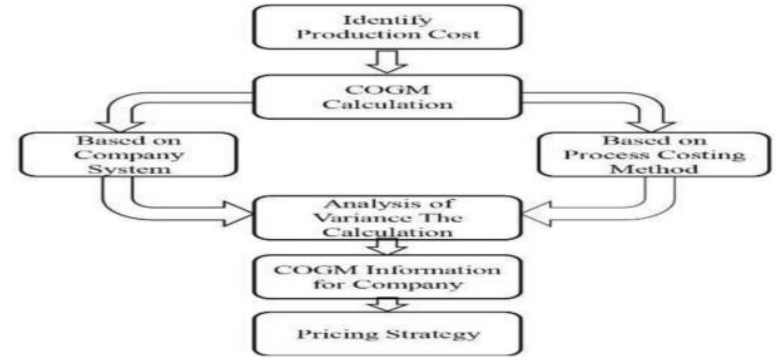

Source: Researcher

Figure 2. Frame of Work

\section{Research Method}

In the SME industry sector, business units rarely bookkeeping completely and using a good accounting system, especially related to the production cost incurred goods each unit, this is intended to discuss the assistance intended for researchers to seek assistance regarding the total cost of producing goods available in industries that have never previously counted accounting and no one has discusses the calculation of production cost at the Amira Collection, differing opinions from large companies that already exist about accounting disability systems that are easily accessible, easier to find selling price and expected amount of profit.

This study is descriptive comparative with a qualitative approach that is knowing and analyzing the calculation COGM of shoe production whether it has been by the cost accounting theory by comparing the calculation COGM by the company method

\section{Data Collection Method}

Preliminary survey. We visited the company, conducted interviews with company owners Mr. Irvan to find out the shoe production being worked on, ask the owner about how the production process, costs incurred in production and how the company calculates the cost of goods manufacture. This preliminary survey is carried out for approximately 3 weeks.

Field survey. Some of the activities carried out by researchers in this field survey include: We looked directly at shoe making activities. Searched for data by conducting interviews with company owners and several employees while directly using raw materials, labor, and factory overhead used for shoe production. We also identified production costs arising from the production process. In this survey, we also reviewed and studied several documents belonging to the company, including details of production costs and production cost reports made by the company each month. The production 
cost report is a very important document in this study, as a comparison with the production cost report which will be presented by researchers based on the cost accounting rules. This field survey is carried out for approximately 3-4 weeks.

Documentary and library research. Data was also obtained through previous studies that have been carried out by other researchers in COGM calculations, studying books, journals and other information related to COGM calculations. Study and library research is carried out for approximately 2 weeks.

\section{Data Analysis Methods}

The steps of the analysis technique carried out in this study are asfollows:

Collect, study and understand data about production activities and data relating to the cost of production and carry out the calculation of the cost of good manufacture begins with

the identification of the production process carried out by the company and the costs used to produce products

Collecting and grouping costs. Identification and classification of costs based on cost of production theory and comparing information on COGM calculated through a process costing with information on the COGM through methods applied by the company.

Arrange conclusions and recommendations for setting selling prices as pricing strategies.

\section{Result And Discussion}

\section{COGM Calculation based on Process Costing}

Amira Collection performs a production in which the product produced is shoes. Of the many types of shoes produced, one of them is a type of flath shoes for women. This type of shoe is produced every month by the company as many as about 10 scores (200 pairs) for stock in warehouses and then routinely sold to its customers. The details of the costs used to produce these flat shoes every month with the calculation based on cost accounting theory are as follows:

Raw Materials Costs. Raw materials costs theoretically should include the cost of all materials used in the manufacture of a product or performance of a service (Barfield, JT; Raiborn, CA and Kinney, 2010). Details of the cost of using raw materials to produce flatshoes every month are as follows:
Table 4. Raw Materials Costs for 10 scores (200 pairs) - per month

\begin{tabular}{|l|r|}
\hline Types of raw materials & Cost (IDR) \\
\hline Newbook AC Material & 620.000 \\
\hline AC Harmony Material & 225.000 \\
\hline Pur CE & 230.000 \\
\hline Tekson $1,3 \mathrm{~mm}$ & 150.000 \\
\hline Sol YY & 275.000 \\
\hline Tamsin Iron 14 & 150.000 \\
\hline Total Direct Materials Cost & 1.650 .000 \\
\hline
\end{tabular}

Source: Researcher Computation (2020)

Supporting Costs/Costs of indirect materials. Similarly classified are materials that actually become parts of the finished product, but whose costs are relatively insignificant, making it not cost-effective to trace them to specific products (Supriyono, 2013 ).

Table 5. Supporting Materials Cost per month

\begin{tabular}{|l|l|c|c|r|}
\hline No. & $\begin{array}{l}\text { Supporting } \\
\text { Material }\end{array}$ & Amount & $@$ Price & Total (IDR) \\
\hline 1 & Ujung keras & 10 & 5.500 & 55.000 \\
\hline 2 & Embos Merk & 10 & 2.500 & 25.000 \\
\hline 3 & PC & 10 & 9.200 & 92.000 \\
\hline 4 & Qbon PU & 10 & 8.300 & 83.000 \\
\hline 5 & Qbon KNG & 10 & 8.200 & 82.000 \\
\hline 6 & Lateks & 10 & 1.000 & 10.000 \\
\hline 7 & Spon 1 $1 / 2$ mI & 10 & 5.700 & 57.000 \\
\hline 8 & Sewing & 10 & 1.255 & 12.550 \\
\hline 9 & Cardboard & 10 & 7.500 & 75.000 \\
\hline 10 & Accessories & 10 & 4.500 & 45.000 \\
\hline 11 & Equipment & & & 300.000 \\
\hline \multicolumn{4}{|l|}{ Total Supporting Materials Cost } & 836.550 \\
\hline
\end{tabular}

Source: Researcher Computation (2020)

Direct labor costs. Direct labor costs are labor cost or wages directly related to production, which are employed to process raw materials into finished goods (Michael R.K, 2011).

Table 6. Direct Labor Costs per month

\begin{tabular}{|l|c|r|r|}
\hline \multicolumn{1}{|c|}{ Type of work } & amount & \multicolumn{1}{|l|}{$\begin{array}{l}\text { Wages/ } \\
\text { scores }\end{array}$} & Total (IDR) \\
\hline Designer & - & - & 500.000 \\
\hline Handyman Top & 10 & 45.000 & 450.000 \\
\hline Handyman down & 10 & 30.000 & 300.000 \\
\hline Insoles & 10 & 3.500 & 35.000 \\
\hline Bensol & 10 & 9.000 & 90.000 \\
\hline Finisher & 10 & 7.500 & 75.000 \\
\hline Meal allowance & 10 & 45.000 & 450.000 \\
\hline \multicolumn{3}{|l|}{ Total Direct Labour Cost } & 1.900 .000 \\
\hline
\end{tabular}

Source: Researcher Computation (2020)

Factory Overhead Costs. Overhead is any factory or production cost that is indirect to manufacturing a product or providing a service (Mulyadi, 2014). 
Table 7. Calculation of Factory Overhead Costs per month

\begin{tabular}{|l|r|}
\hline Expenses & Amount (IDR) \\
\hline Electricity & 112.500 \\
\hline Telephone & 90.000 \\
\hline Engine and Vehicle Maintenance & 131.250 \\
\hline Depreciation Machines and Vehicles & 62.805 \\
\hline Building maintenance & 37.500 \\
\hline Depreciation Building & 75.000 \\
\hline Total Factory Overhead & 509.055 \\
\hline
\end{tabular}

Source: Researcher Computation (2020)

\section{Calculation Cost of Goods Manufacture}

Shoe companies process their products through one department. During the management phase, a small portion of the product is damaged and unsold for sale. Production and cost data are products entering the process of 200 pairs of shoes, of which 175 pairs of shoes have been completed and as many as 5 pairs of damaged products and 20 are still in process with completion rates (Raw Material Cost $100 \%$, Supporting Material Cost $100 \%$, Direct labor Cost 80\%, Factory Overhead Cost 70\%).

Table 8. Calculation COGM Per Unit

\begin{tabular}{|l|c|l|c|}
\hline $\begin{array}{l}\text { Element } \\
\text { Production } \\
\text { Cost (1) }\end{array}$ & $\begin{array}{l}\text { Total Cost } \\
\text { (IDR) }(2)\end{array}$ & $\begin{array}{c}\text { Equivalence Unit } \\
(3))\end{array}$ & $\begin{array}{c}\text { COGM/pair } \\
\text { (IDR) (2):(3) }\end{array}$ \\
\hline Material & 1.650 .000 & $\begin{array}{l}175+5+(100 \% \mathrm{x} \\
20)=200 \text { pairs }\end{array}$ & 8,250 \\
\hline Supporting & 836.550 & $\begin{array}{l}175+5+(100 \% \mathrm{x} \\
20)=200 \text { pairs }\end{array}$ & $4,182.75$ \\
\hline Labour & 1.900 .000 & $\begin{array}{l}175+5+(80 \% \mathrm{x} \\
20)=196 \text { pairs }\end{array}$ & $9,693.88$ \\
\hline Overhead & 509.055 & $\begin{array}{l}175+5+(70 \% \mathrm{x} \\
20)=194 \text { pairs }\end{array}$ & $2,623.9$ \\
\hline Total & $4,895,605$ & \multicolumn{2}{|l}{} \\
\hline
\end{tabular}

Source: Researcher Computation (2020)

Equivalent Unit Calculation. Equivalent units of production (EUP) are an approximation of the number of whole units of output that could have been produced during a period from the actual effort expended during that period (Barfield, JT; Raiborn, CA and Kinney, 2010). The formula to calculate Unit equivalent is : (Finished products + damaged products + (products in process $\mathrm{x} \%$ complation) (Mulyadi, 2014). From the results of the above calculation, the cost of good manufacture report is made as a basis or reference in determining the selling price.

Table 9. COGM Statement (Process Costing method) Per Month

\begin{tabular}{|l|c|c|}
\hline \multicolumn{2}{|l|}{ PRODUCTION DATA } & 200 pairs \\
\hline Entered in the process & & 175 pairs \\
\hline $\begin{array}{l}\text { Finished products are } \\
\text { transferred to the } \\
\text { warehouse }\end{array}$ & & 20 pairs \\
\hline Product in final process & & 5 pairs \\
\hline Damaged product & & \\
\hline
\end{tabular}

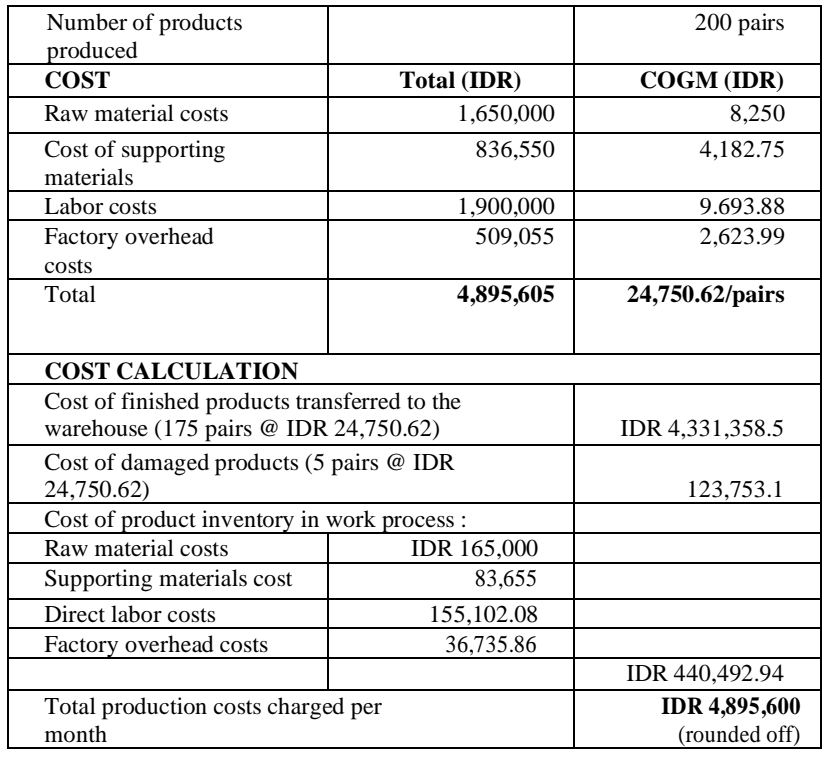

Source: Researcher Computation (2020)

This production cost report becomes very useful information for management for pricing strategy. Information on this production cost report will be compared with information on the calculation of production costs that the company has traditionally carried out.

\section{Company's COGM Calculation}

The details of the costs used to produce these flatshoes every month based on company calculation are as follows:

Table 10. COGM Statement (Company's Calculation) per month

\begin{tabular}{|c|c|c|c|c|}
\hline No & Explanation & Price/pair & Amount & $\begin{array}{c}\text { Total Price } \\
\text { (IDR) }\end{array}$ \\
\hline 1 & $\begin{array}{c}\text { Raw material } \\
\text { cost }\end{array}$ & estimate & estimate & 1.500 .000 \\
\hline 2 & $\begin{array}{c}\text { Supporting } \\
\text { material cost }\end{array}$ & estimate & estimate & 550.450 \\
\hline 3 & $\begin{array}{c}\text { Direct labour } \\
\text { cost }\end{array}$ & estimate & estimate & 2.150 .000 \\
\hline 4 & Overhead cost & estimate & estimate & 275.250 \\
\hline COGM & & 4.475 .700 \\
\hline Unit Production & 200 pair \\
\hline \multicolumn{2}{|l}{ COGM/pairs } \\
\hline
\end{tabular}

Source: Researcher Computation (2020)

\section{Comparative Analysis of COGMCalculations}

The results of the analysis that has been done, there is variance between the results of COGM calculations conducted by Amira Collection with the results of COGM calculations based on process costing (tabel 11).

Based on the monthly production cost report document made by the company there is a variance in COGM calculation 
figures. This variance is due to the calculation using cost accounting rules in detail for the allocation of each cost, especially for the use of raw material costs, the cost of supporting materials to factory overhead costs. The company's COGM calculations ignores the depreciation expense, equipment usage costs and other overhead costs that should still be calculated even though the value is not large. Because it is attached to the product produced.

Table 11. Analysis Variance of COGM Calculation (in IDR)

\begin{tabular}{|l|c|c|c|c|}
\hline $\begin{array}{l}\text { Elements } \\
\text { of costs }\end{array}$ & $\begin{array}{l}\text { Amir } \\
\text { Collection }\end{array}$ & $\begin{array}{l}\text { Process } \\
\text { Costing }\end{array}$ & Variance & Explanation \\
\hline $\begin{array}{l}\text { Raw } \\
\text { Material } \\
\text { costs }\end{array}$ & 1.500 .000 & 1.650 .000 & 150.000 & $\begin{array}{l}\text { The detailed process } \\
\text { costing calculation } \\
\text { allocates costs } \\
\text { according to usage }\end{array}$ \\
\hline $\begin{array}{l}\text { The detailed process } \\
\text { Material } \\
\text { Costs }\end{array}$ & 550.450 & 836.550 & 286.100 & $\begin{array}{l}\text { costing calculation } \\
\text { allocates costs } \\
\text { according to usage }\end{array}$ \\
\hline $\begin{array}{l}\text { Direct } \\
\text { Labour } \\
\text { Costs }\end{array}$ & 2.000 .000 & 1.900 .000 & 100.000 & $\begin{array}{l}\text { Palcuss costing } \\
\text { on the percentage of } \\
\text { completion rate of } \\
\text { the work }\end{array}$ \\
\hline $\begin{array}{l}\text { Overhead } \\
\text { Costs }\end{array}$ & 275.250 & 509.055 & 233.805 & $\begin{array}{l}\text { Process costing } \\
\text { alculations in detail } \\
\text { allocate costs } \\
\text { according to the use } \\
\text { of the calculation of } \\
\text { depreciation }\end{array}$ \\
\hline $\begin{array}{l}\text { COGM/ } \\
\text { month }\end{array}$ & 4.475 .700 & 4.895 .605 & 419.900 & \\
\hline $\begin{array}{l}\text { COGM/ } \\
\text { pairs }\end{array}$ & $22.378,5$ & $24.750,62$ & $2.372,12$ & \\
\hline
\end{tabular}

Source: Researcher Computation and analysis (2020)

As a strategy to determine the selling price of shoes, companies can use one type of pricing strategy, namely profit oriented with the desired profit percentage. COGM per pairs is the basis for the calculation. For example, a company wants to get a profit of $60 \%$ of its cost, the selling price of the shoes are :

COGM (per pairs) :IDR 24.750,62,-, Desired percentage of profit $(60 \%)$ : IDR 14.850,37,-

So we can get the Selling price is IDR 39.600,- (rounded off)

This is the gross selling price. Ussually the company will add it to non-production costs such as marketing and administrative costs. So that the resulting selling price of products to obtain the expected profits. The precise and through calculation of COGM provides decisions for management in managing pricing strategies so that the company can continuously obtain the desired maximum profits.

\section{CONCLUSION}

The results and discussion of the above research can be concluded that SMEs Amira Collection should identify the production costs in detail so that it will produce maximum profit with the selling price that is still in the normal level, so that the company can maintain its business with the maximum profit and shoe production will continue to run at this SME because the COGM calculation can properly be the company's strategy to determine the selling price.

We can calculate the COGM using the variable method or the full method to determine the variable costs and fixed costs that we use in production in further research development. And we can do quantitative research to determine how the relationship or effect between COGM and selling prices. We can also expand research objects at the National or International SME scale.

\section{REFERENCES}

Barfield, JT; Raiborn, CA and Kinney, M. (2010). Cost Accounting: Traditions and Innovations. Thomson Learning.

Brassington, F and Pettitt, S. (2013). Essentials of marketing, 3rd ed. Pearson.

Garrison, R.H; Noreen, W.E; Brewer, P. . (2013). Accouting Managerial. Salemba Empat.

Michael Colin Cant, Jan Wiid, C. M. S. (2016). Key Factors Influencing Pricing Strategies For Small Business Enterprises (SMEs): Are They Important? The Journal of Applied Business Research - November/December 2016, 32 No.6(The Clute Institute), 1737-1750.

Michael R.K, C. A. . (2011a). Cost Accounting: Foundations and Evolutions, (8th ed.). Cengage Learning.

Mulyadi. (2014). Cost Accounting, 6th Edition. UPP STIM YKPN.

Supriyono, R. (2013). Cost Accounting and Costing Pricing. BPFE-Yogyakarta.

Vanderberck, E. J. (2009). Principles of Cost Accounting (15th ed.). Cengage Learning. 